\title{
Using Machine Learning Algorithms to Predict People's Intention to Use Mobile Learning Platforms During the COVID-19 Pandemic: Machine Learning Approach
}

Iman Akour $^{1^{*}}, \mathrm{PhD} ;$ Muhammad Alshurideh ${ }^{2,3^{*}}, \mathrm{PhD}$; Barween Al Kurdi ${ }^{4^{*}}, \mathrm{PhD}$; Amel Al Ali ${ }^{{ }^{*}}, \mathrm{PhD} ;$ Said Salloum ${ }^{5^{*}}$, $\mathrm{PhD}$

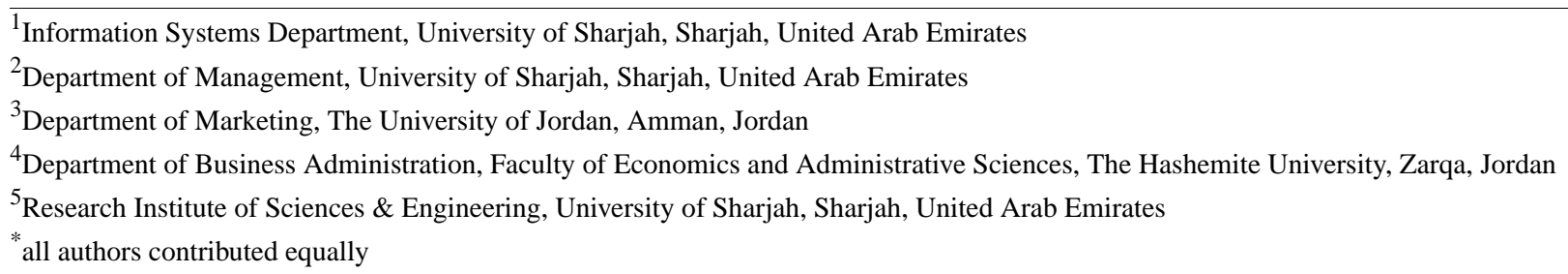

Corresponding Author:

Said Salloum, $\mathrm{PhD}$

Research Institute of Sciences \& Engineering

University of Sharjah

Academic City

Sharjah

United Arab Emirates

Phone: 971507679647

Email: salloum78@live.com

\section{Abstract}

Background: Mobile learning has become an essential instruction platform in many schools, colleges, universities, and various other educational institutions across the globe, as a result of the COVID-19 pandemic crisis. The resulting severe, pandemic-related circumstances have disrupted physical and face-to-face contact teaching practices, thereby requiring many students to actively use mobile technologies for learning. Mobile learning technologies offer viable web-based teaching and learning platforms that are accessible to teachers and learners worldwide.

Objective: This study investigated the use of mobile learning platforms for instruction purposes in United Arab Emirates higher education institutions.

Methods: An extended technology acceptance model and theory of planned behavior model were proposed to analyze university students' adoption of mobile learning platforms for accessing course materials, searching the web for information related to their disciplines, sharing knowledge, and submitting assignments during the COVID-19 pandemic. We collected a total of 1880 questionnaires from different universities in the United Arab Emirates. Partial least squares-structural equation modeling and machine learning algorithms were used to assess the research model, which was based on the data gathered from a student survey.

Results: Based on our results, each hypothesized relationship within the research model was supported by our data analysis results. It should also be noted that the J48 classifier ( $89.37 \%$ accuracy) typically performed better than the other classifiers when it came to the prediction of the dependent variable.

Conclusions: Our study revealed that teaching and learning could considerably benefit from adopting remote learning systems as educational tools during the COVID-19 pandemic. However, the value of such systems could be lessened because of the emotions that students experience, including a fear of poor grades, stress resulting from family circumstances, and sadness resulting from a loss of friends. Accordingly, these issues can only be resolved by evaluating the emotions of students during the pandemic.

(JMIR Med Educ 2021;7(1):e24032) doi: 10.2196/24032

\section{KEYWORDS}

COVID-19; pandemic; mobile learning; fear; technology acceptance model; theory of planned behavior; prediction; intent; online learning; machine learning; behavior 


\section{Introduction}

\section{Background}

Colleges and universities often actively aim to create web-based teaching environments with the help of relevant learning platforms and resources [1-3]. In addition, these higher education institutions attempt to achieve effective student results by providing various learning management platforms that enhance strategies and practices for teaching and learning. However, the COVID-19 pandemic has presented higher education institutions with several challenges, as students worldwide have been experiencing negative emotions and feelings with regard to their studies. Such emotions include fear, anxiety, and apprehension. A consequence of these negative emotions is stigmatization, which students who are mentally affected by fear often experience. In addition, students have experienced discrimination, loss, and various other psychosocial issues after COVID-19 was declared a pandemic [4-6]. The lockdown effect has also had an impact on students' fear; the need for e-learning became critical when education institutes were forced to halt their contact learning and teaching practices. Furthermore, students' fear can manifest as a fear of taking risks, a fear of failure, a fear of missing out, and fear resulting from insecurity [7-10]. Students' fear can also impact technology adoption, as the COVID-19 lockdown has forced universities, colleges, and schools to implement distance learning in an attempt to lessen the harmful effects of COVID-19 and maintain student learning.

A considerable percentage of colleges and universities have experienced issues that relate to educators' experience with using technology for teaching and learning. The technological proficiency of students is also problematic, as classes need to be conducted via web-based methods [11-15]. However, adopting technology for distance learning is essential for efficiently validating the conduction of web-based classes [16-19]. According to the majority of technology adoption studies, there are complications with regard to the adoption process, as technology adoption can affect other teaching and learning factors, such as learning strategies, learning contexts, and technology availability.

Although several researchers have focused on technology adoption in their research, the adoption of creative teaching methods (eg, the use of mobile learning apps) as a result of the COVID-19 pandemic and other similar disasters has yet to be explored. It has become quite easy to find mobile learning apps on both the Apple Store and Google Play Store. Users can access mobile learning apps from these stores, which are responsible for automatically updating these apps. In addition, users have been increasingly accessing these apps because of app stores' freemium approach [20,21]. However, students' and educators' thoughts on implementing a mobile learning platform during the pandemic must be considered. Therefore, the need for mobile learning platforms and the issues surrounding the COVID-19 pandemic need to be addressed [22]. As the use of mobile learning platforms is a relatively new practice, there is a lack of research on how mobile learning can influence higher education. Furthermore, although the technology adoption domain has undergone extensive research, there has been a lack of focus on the emotion of fear when considering the adoption of technology during the COVID-19 pandemic. Past studies have mostly dealt with the technological factors in teaching and learning, without paying any attention to psychological factors. The impact of fear on technology adoption has yet to be clearly understood, and this is often the reason why technology has not been used to its full potential when it comes to the education domain [23].

After taking into consideration the limitations of technology adoption in education, we aimed to provide educational information on appropriate technology use, for times when learners and educators are fearful of technology. This is particularly relevant at times (eg, the COVID-19 pandemic) when technology use becomes imperative for providing better education to both learners and educators, who are often novices in terms of using technological applications for teaching and learning.

When it comes to the academic research adoption model, studies have found that using the technology acceptance model (TAM) and the theory of planned behavior (TPB) model as a hybrid model is effective for technology adoption. With the help of these models, it becomes possible to determine users' willingness to accept and use technology [24,25]. Accordingly, this study focuses on understanding students' and educators' willingness to use mobile learning systems, by using the TPB model and TAM, in addition to 2 external factors (ie, subjective norms [SNs] and fear). As a result, we were able to use the TAM and TPB model to investigate students' and teachers' thoughts on using machine learning methods during the spread of COVID-19. In addition, assessments of fear during the COVID-19 pandemic and how fear directly affects the TAM and TPB model have been limited. After considering the lack of research, we aimed to develop a hybrid model that can determine the different fears that both learners and educators may face during the COVID-19 pandemic. Since we investigated the factor of fear, we believe that our research paper has an increased chance of providing both teachers and app developers with the technology and education-related information needed for developing and implementing new technologies during the COVID-19 lockdown period.

The unique educational problems that have emerged during these unordinary times can be highlighted if more information on the factors of machine learning adoption at the time of the COVID-19 pandemic is gathered. COVID-19-related literature on the technology adoption domain can benefit higher education institutions on a theoretical and practical level.

\section{Literature Review}

Previous research studies on technology adoption have focused on the various forms of fear $[23,26]$. For example, anxiety is an important factor that helps manage technology approval and apprehension. Within the education sector, the adoption of technology by students is influenced by anxiety [27]. Furthermore, apart from anxiety, a lack of experience and skills may also influence technology use. The fear of using technology, combined with poor technological literacy and anxiety, negatively affects the adoption of technology. Hence, it is 
essential for teachers and educators to focus on psychological development and help students accept the use of technology. Other factors of the fear of using technology within the educational sector include technical readiness and preparedness; technology adoption is negatively influenced by both of these factors [28-30].

The education sector is not the only sector that has exhibited a fear of technology adoption. Medical sector students usually perceive risks and exhibit negative anxiety when technology is used [31,32]. In addition, health anxiety is one of the top concerns of the health care sector. Health anxiety includes the apprehension of patients and the fear of receiving results about a severe illness. With regard to the banking sector, various kinds of fear that relate to customers' perceptions and attitudes toward technology have been recognized. Customers do not want to use their data for mobile payments. Customers fear the use of technology in mobile banking and are negatively influenced by the frauds that have occurred. As a result, they lack both technological experience and trust in technology $[33,34]$. With regard to the household sector, the main reasons why technology is not being used include the fear of using technology and the fear that technology will increase the number of family tasks [23].

Various research studies have assessed the issues that relate to technological acceptance and fear. These research studies are based on the TAM [29,30,32-35] and several other models [28,31,36,37], and most of these research studies have assessed how the fear of technology can influence technology acceptance. Various technology users have provided justifications for their fear of technology use. For example, several users have stated that their fear is related to self-confidence. Errors are made when a human is assigned to a job, and excessively worrying about this fact enhances fear [38]. Moreover, several users have stated that they do not use technology because they believe that technology is time-consuming, and therefore does not allow them to complete their tasks [39]. Various technology acceptance studies have assessed the influence of fear on the breach of data privacy, and this is why privacy and security awareness are emphasized in technology research studies [40].

Previous studies have not provided sufficient empirical research on the use of mobile learning in United Arab Emirates (UAE) institutions, nor have they considered the factors that influence students' actual technology use. When it comes to methodology, technology acceptance researchers have typically analyzed theoretical models by using structural equation modeling and machine learning algorithms. After considering various theoretical models, we conducted this study with the following 2 objectives: (1) examine how students use mobile learning by integrating the TAM [41] and TPB model [42] into 1 theoretical model, and (2) validate the created theoretical model with the help of machine learning and partial least squares-structural equation modeling (PLS-SEM) algorithms.

\section{Theoretical Model and Research Model}

\section{Model Design}

In this study, the research model was developed to integrate the $\mathrm{SN}$ and fear constructs into 2 kinds of theoretical models- the TAM and TPB model. We believed that the SN and fear would influence the perceived ease of use (PEOU) and perceived usefulness (PU) of mobile learning systems. Additionally, we believed that attitude and perceived behavioral control (PBC) would be influenced by the continuous intention to use mobile learning systems. The proposed theoretical model is presented in Figure 1.

Figure 1. Study model.

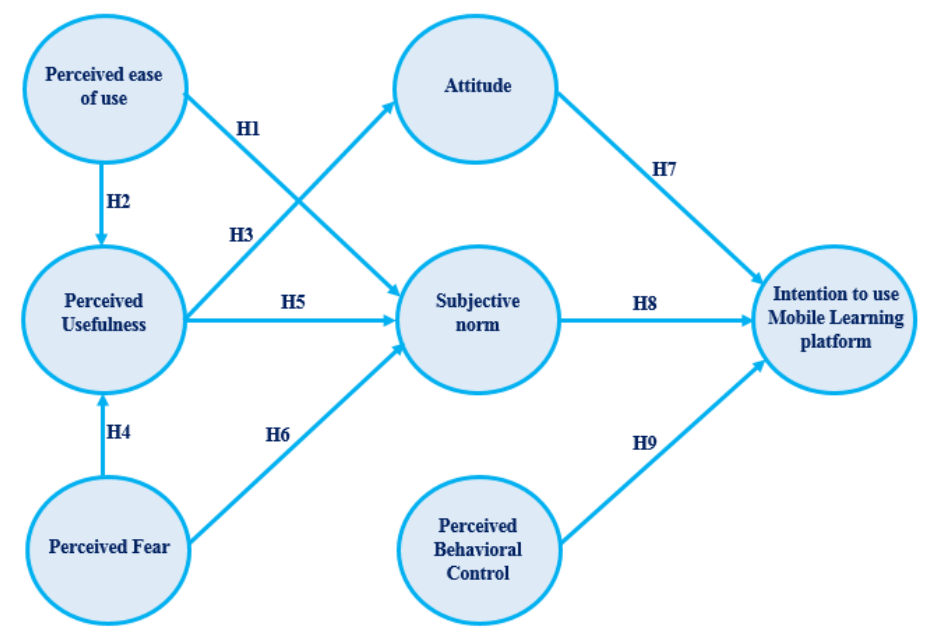

\section{TAM}

One of the main objectives of the TAM is to validate external factors based on personal belief. The model is considered quite powerful, since it can be used to explain individuals' ability to accept the technology at their educational institutions [41,43-45]. According to the TAM, the 2 kinds of perceptions that can be measured are PU and the PEOU. This means that the behavioral intention of the user can be influenced directly. PU should be considered because this factor helps with measuring the degree to which technology must be evaluated by an individual, and assessing whether a technology is useful enough to be adopted and accepted. However, the PEOU refers to the degree to which an individual believes that technology is manageable and attainable [41]. 
In the context of technology acceptance, attitude has been defined as a user's desire to use a system [46]. Previous mobile learning studies have indicated that behavioral intention and attitude are related to each other. Previous research has also suggested that the intention to use mobile learning systems is significantly influenced by attitude [47-50].

Keeping in mind the previous assumptions, it can be concluded that if technology is considered to be easy to use, then users will retain a positive attitude. Therefore, user perceptions are quite important. If users have a positive attitude, it is believed that the users will adopt technology. The following hypotheses were proposed after applying the previous assumptions to the research model: (1) the PEOU will predict the SN (ie, H1), (2) the PEOU will predict PU (ie, H2); (3) PU will predict attitude (ie, H3), (4) PU will predict the SN (ie, H5), and (5) people's attitudes will predict their intention to use a mobile learning platform (ie, H7).

\section{SN}

Individual perceptions can be measured by using a tool called the SN, which is a type of perception that is based on the presence of individuals who exhibit similar attitudes and behaviors toward technology. The TAM is strengthened by the $\mathrm{SN}$, since the TAM has been enabled to integrate user behaviors that are present within a user group [51]. The $\mathrm{SN}$ is an external factor that includes students' intentions to adopt mobile learning technology for classmate group meetings.

Various literature on technology adoption or acceptance have shown that the SN also influences behavioral intention, $\mathrm{PU}$, and the PEOU [45,52-54]. The SN and TAM have recently been used as external factors in a study by Huang et al [55], who stated that the TAM-embedded factors from various research studies had a significantly close relationship with external factors. However, they found that the external factor SN was not efficiently or deeply implemented in other studies. Previous studies have stated that the intention of using mobile learning platforms is significantly influenced by the SN [49,50,56-58]. Hence, the following hypothesis was developed: the SN will predict people's intention to use a mobile learning platform (ie, H8).

\section{Perceived Fear}

On December 2019, the novel COVID-19 disease was observed in China, and with time, it spread throughout the world. Based on recent studies, the reaction toward the perceived threat of the SARS-CoV-2 virus has been fear. Additionally, the Health Anxiety Inventory scale has shown that fear is at the highest level [59]. Even though fear is perceived to be positive when real dangers are present, fear in the context of the COVID-19 pandemic may be burdensome and chronic. There are various forms of fear that are related to the COVID-19 pandemic, including health anxiety, uncertainty, and the fear of the risk of losing loved ones. The COVID-19 pandemic has resulted in the development of 2 vital issues, as follows: a high degree of worrying and a high possibility of being affected by the disease $[4,60]$.

This study aimed to analyze the association between the adoption of technology and the external factor perceived fear (PF), through the use of the TAM. In this study, TAM limitations needed to be overcome. Such limitations include the implementation of external factors that are specific to the analysis of a TAM for PF, including PU, the PEOU, and the SN [61]. Hence, the following hypotheses were developed while keeping these factors in mind: PF will predict PU (ie, H4), and $\mathrm{PF}$ will predict the $\mathrm{SN}$ (ie, H6).

\section{$P B C$}

PBC is defined as "people's perception of the ease or difficulty of performing the behavior of interest" [62]. Previous research has shown that the intention to use mobile learning platforms is significantly affected by PBC $[49,50,63]$. Hence, the following hypothesis was proposed: $\mathrm{PBC}$ will predict people's intention to use mobile learning platforms (ie, H9).

Our hypotheses were used to develop the proposed research model, as indicated in Figure 1. The theoretical model was presented as a structural equation model and analyzed with machine learning methods.

\section{Methods}

\section{Context and Subjects}

University students were the target population for this study. The questionnaire was disseminated to university students in the UAE. In total, 7 well-known universities in the UAE were chosen for this study, namely the University of Sharjah, the Higher Colleges of Technology, The British University in Dubai, United Arab Emirates University, the University of Fujairah, American University in UAE, and Ajman University. We used a web-based survey to collect data from May to June 2020. The surveys were completed by the participants, who did not ask for any compensation. In this study, the convenience sampling technique was used for data collection. In total, 2000 surveys were distributed, and a 94\% response rate was recorded (ie, 1880 students completed the whole survey). The number of males and females who completed the survey was $1102(58.6 \%)$ and $778(41.4 \%)$, respectively.

The percentage of participants aged 18-29 was $40.3 \%$ (758/1880), and the remaining $59.7 \%$ of participants $(1122 / 1880)$ were older than 29 years. Furthermore, 33.3\% $(626 / 1880)$ of the participants were undergraduate students, $45.2 \%(849 / 1990)$ were master students, $11.1 \%$ (209/1880) were $\mathrm{PhD}$ students, and $10.4 \%(196 / 1880)$ were diploma students. A comprehensive view of the collected data is provided in Tables 1 and 2. 
Table 1. Number of students $(\mathrm{N}=1880)$ in participating universities.

\begin{tabular}{ll}
\hline University & Number of students, $\mathrm{n}$ \\
\hline United Arab Emirates University & 568 \\
University of Sharjah & 439 \\
Higher Colleges of Technology & 365 \\
Ajman University & 287 \\
The British University in Dubai & 103 \\
University of Fujairah & 68 \\
American University in United Arab Emirates & 50 \\
\hline
\end{tabular}

Table 2. Summary of students' demographic characteristics.

\begin{tabular}{ll}
\hline Variables & Participants, $\mathrm{n}(\%)$ \\
\hline Gender & $1102(58.6)$ \\
Male & $778(41.4)$ \\
Female & \\
Age (years) & $758(40.3)$ \\
$18-29$ & $635(33.7)$ \\
$30-39$ & $367(19.5)$ \\
$40-49$ & $120(6.5)$ \\
$50-59$ & $196(10.4)$ \\
Level of education & $626(33.3)$ \\
Diploma & $849(45.2)$ \\
Bachelor degree & $209(11.1)$ \\
Master degree & \\
PhD degree & \\
\hline
\end{tabular}

\section{Study Design}

This study's design consisted of 2 parts. The first part focused on collecting participants' demographic data. The second part focused on collecting responses that were related to the factors

in the conceptual model's 5-point Likert scale. To assess the 7 constructs (ie, attitude, intention to use a mobile learning platform, SN, PBC, PF, PEOU, and PU) in the questionnaire, 20 items were included in the survey. The sources of these constructs are presented in Table 3.

Table 3. Constructs and their sources.

\begin{tabular}{lll}
\hline Construct & Number of items, $\mathrm{n}$ & Source, authors \\
\hline Attitude & 3 & Al-Emran et al [49], Cheon et al [50] \\
Intention to use a mobile learning platform & 2 & Al-Emran et al [49], Tan et al [64], Bao et al [65] \\
Subjective norm & 3 & Al-Emran et al [49], Cheon et al [50] \\
Perceived behavioral control & 3 & Al-Emran et al [49], Cheon et al [50] \\
Perceived fear & 3 & Developed in this study. \\
Perceived ease of use & 3 & Al-Emran et al [49], Tan et al [64], Bao et al [65] \\
Perceived usefulness & 3 & Al-Emran et al [49], Tan et al [64], Bao et al [65] \\
\hline
\end{tabular}

\section{Questionnaire Pretest}

Before conducting the final survey, it was important to make sure that the questionnaire items were reliable by conducting a pilot study with a random selection of 100 students from the target population. We calculated Cronbach $\alpha$ values to measure the internal reliability of the items of each construct. Nunnaly and Bernstein [66] have suggested that an acceptable reliability coefficient should equal at least .70. Table 4 shows that this study's constructs had Cronbach $\alpha$ values of $>$.70. Therefore, each construct was reliable. This meant that each construct could be used in the final research model. 
Table 3 shows that the questionnaire's 5-point Likert scales were reliable. Therefore, the measurement scales could be used in this study.

Table 4. Cronbach $\alpha$ values for the pilot study (Cronbach $\alpha \geq .70$ ).

\begin{tabular}{ll}
\hline Construct & Cronbach $\alpha$ \\
\hline Attitude & .736 \\
Intention to use a mobile learning platform & .755 \\
Subjective norm & .864 \\
Perceived behavioral control & .859 \\
Perceived fear & .847 \\
Perceived ease of use & .887 \\
Perceived usefulness & .803 \\
\hline
\end{tabular}

\section{Results}

\section{Data Analysis}

The theoretical model developed in this study was evaluated by using 2 different techniques. The first technique involved PLS-SEM and the use of the SmartPLS (SmartPLS GmbH) tool [67]. This study used the PLS-SEM technique, mainly because both the structural and measurement models could be concurrently analyzed through PLS-SEM, thereby increasing the preciseness of results [68]. As for the second technique, we predicted the dependent variables of the conceptual model with the help of machine learning algorithms in Weka (University of Waikato) [69].

\section{Model Reliability and Validity Assessment}

We assessed the validity and reliability of the measurement model [70]. Model reliability was tested by using Cronbach $\alpha$ and composite reliability measures. It has been suggested that these measures must equal at least .70 to be acceptable [70]. As per the results in Table 5, model reliability was confirmed, as satisfactory values were attained for both measures.

According to Hair Jr et al [70], discriminant and convergent validities can be evaluated to test model validity. We calculated the factor loading and average variance extracted values of each construct item to determine convergent validity. It has been suggested that the average variance extracted and factor loading values must equal at least .50 [71] and .70 [72], respectively, to be acceptable. As per the results in Table 5, convergent validity was confirmed, as accepted values were attained for both measures. Furthermore, Henseler et al [73] have suggested that the Heterotrait-Monotrait ratio of correlations can be calculated to determine discriminant validity. Heterotrait-Monotrait ratio values must fall below .85 to be acceptable. As per the results in Table 6, discriminant validity was confirmed, as accepted Heterotrait-Monotrait ratio values were attained. 
Table 5. Convergent validity test results. Acceptable values (ie, factor loading, Cronbach $\alpha, \mathrm{CR}^{\mathrm{a}} \geq 0.70$, and $\mathrm{AVE}^{\mathrm{b}}>0.5$ ) were obtained.

\begin{tabular}{|c|c|c|c|c|}
\hline Constructs and items & Factor loading & Cronbach $\alpha$ & $\mathrm{CR}$ & AVE \\
\hline Attitude & & .798 & .823 & .760 \\
\hline ATT1 & .726 & & & \\
\hline ATT2 & .886 & & & \\
\hline ATT2 & .800 & & & \\
\hline Intention to use a mobile learning platform & & .739 & .789 & .703 \\
\hline INT1 & .846 & & & \\
\hline INT2 & .805 & & & \\
\hline Subjective norm & & .758 & .811 & .716 \\
\hline SN1 & .819 & & & \\
\hline $\mathrm{SN} 2$ & .795 & & & \\
\hline SN3 & .883 & & & \\
\hline Perceived behavioral control & & .843 & .771 & .652 \\
\hline $\mathrm{PBC} 1$ & .822 & & & \\
\hline $\mathrm{PBC} 2$ & .873 & & & \\
\hline PBC3 & .778 & & & \\
\hline Perceived fear & & .779 & .798 & .593 \\
\hline PF1 & .808 & & & \\
\hline PF2 & .845 & & & \\
\hline PF3 & .866 & & & \\
\hline Perceived ease of use & & .769 & .746 & .633 \\
\hline PEOU1 & .872 & & & \\
\hline PEOU2 & .832 & & & \\
\hline PEOU3 & .857 & & & \\
\hline Perceived usefulness & & .715 & .750 & .785 \\
\hline PU1 & .878 & & & \\
\hline PU2 & .906 & & & \\
\hline PU3 & .848 & & & \\
\hline
\end{tabular}

${ }^{\mathrm{a}} \mathrm{CR}$ : composite reliability.

b AVE: average variance extracted. 
Table 6. HTMT ${ }^{\mathrm{a}}$ ratios of correlations between each construct.

\begin{tabular}{|c|c|c|c|c|c|c|c|}
\hline Construct & Attitude & $\begin{array}{l}\text { Intention to use a } \\
\text { mobile learning plat- } \\
\text { form }\end{array}$ & $\begin{array}{l}\text { Subjective } \\
\text { norm }\end{array}$ & $\begin{array}{l}\text { Perceived } \\
\text { behavioral } \\
\text { control }\end{array}$ & $\begin{array}{l}\text { Perceived } \\
\text { fear }\end{array}$ & $\begin{array}{l}\text { Perceived ease } \\
\text { of use }\end{array}$ & $\begin{array}{l}\text { Perceived } \\
\text { useful- } \\
\text { ness }\end{array}$ \\
\hline Attitude, HTMT ratio & $-b$ & .480 & .519 & .377 & .330 & .549 & .651 \\
\hline $\begin{array}{l}\text { Intention to use a mobile learning } \\
\text { platform, HTMT ratio }\end{array}$ & .480 & - & .299 & .583 & .514 & .350 & .504 \\
\hline Subjective norm, HTMT ratio & .519 & .299 & - & .516 & .460 & .393 & .511 \\
\hline $\begin{array}{l}\text { Perceived behavioral control, } \\
\text { HTMT ratio }\end{array}$ & .377 & .583 & .516 & - & .602 & .657 & .542 \\
\hline Perceived fear, HTMT ratio & .330 & .514 & .460 & .602 & - & .263 & .494 \\
\hline Perceived ease of use, HTMT ratio & .549 & .350 & .393 & .657 & .263 & - & .333 \\
\hline Perceived usefulness, HTMT ratio & 651 & .504 & .511 & .542 & .494 & .333 & - \\
\hline
\end{tabular}

${ }^{\mathrm{a}}$ HTMT: Heterotrait-Monotrait ratio.

${ }^{\mathrm{b}}$ Not applicable.

\section{Hypotheses Testing and Coefficient of Determination}

The 9 hypotheses we proposed were tested by using the structural equation modeling procedure [74]. Analyses were carried out to determine the variance (ie, the $\mathrm{R}^{2}$ value) of each path, the variance of the research model, and the significance of each hypothesized path association. Figure 2 and Table 7 show the standardized path coefficients and path significances.

The $\mathrm{R}^{2}$ values for attitude, intention to use a mobile learning platform, the SN, and PU ranged between 0.391 and 0.575 , as shown in Table 7 . Hence, these constructs had a moderate predictive power [75]. Based on the hypothesis data analysis, the empirical data supported every hypothesis (ie, H1, H2, H3, H4, H5, H6, H7, H8, and H9).
Table 8 and Figure 2 summarize the results of the hypotheses tests, which indicated that the SN significantly influenced the PEOU $(\beta=.756 ; P=.001), P U(\beta=.227 ; P=.03)$ and $P F(\beta=.480$; $P=.04)$. These results supported hypotheses H1, H5, and H6, respectively. PU had significant effects on attitude $(\beta=.801$; $P<.001$ ), which supports hypothesis H3. The results also revealed that the intention to use a mobile learning platform significantly influenced attitude $(\beta=.707 ; P<.001)$, the SN $(\beta=.553, P<.001)$, and PBC $(\beta=.148, P<.001)$. These results supported hypotheses $\mathrm{H} 7, \mathrm{H} 8$, and $\mathrm{H} 9$, respectively. Additionally, the results show that PU was significantly influenced by the PEOU $(\beta=.264 ; P=.002)$ and PF $(\beta=.358$; $P=.04)$. These results supported hypotheses $\mathrm{H} 2$ and $\mathrm{H} 4$, respectively.

Figure 2. Hypotheses testing results. The $\mathrm{R}^{2}$ values reported are for perceived usefulness, attitude, the subjective norm, and the intention to use a mobile learning platform. The $\beta$ values and statistical significance of each path are also reported. *significant at $P<.05, * *$ significant at $P \leq .01$.

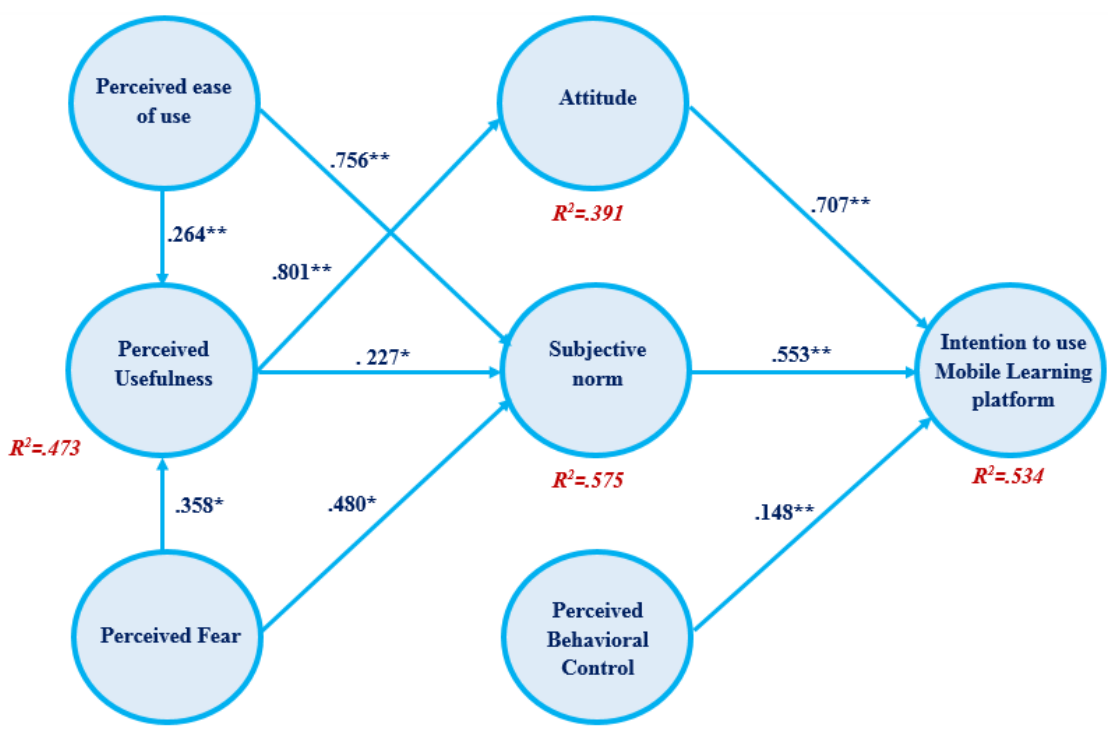


Table 7. $\mathrm{R}^{2}$ values of the endogenous latent variables.

\begin{tabular}{lll}
\hline Constructs & $\mathrm{R}^{2}$ & Predictive power \\
\hline Perceived usefulness & 0.473 & Moderate \\
Attitude & 0.391 & Moderate \\
Subjective norm & 0.575 & Moderate \\
Intention to use a mobile learning platform & 0.534 & Moderate \\
\hline
\end{tabular}

Table 8. Summary of hypotheses testing results.

\begin{tabular}{|c|c|c|c|c|c|c|}
\hline Hypothesis & Relationship & Path $\beta$ & $t$ test $(\mathrm{df})^{\mathrm{a}}$ & $P$ value & $\begin{array}{l}\text { Correlation } \\
\text { direction }\end{array}$ & Decision \\
\hline H1 & Perceived ease of use and subjective norm & .756 & $18.179(1876)$ & .001 & Positive & Supported ${ }^{\mathrm{b}}$ \\
\hline $\mathrm{H} 2$ & Perceived ease of use and perceived usefulness & .264 & $10.203(1876)$ & .002 & Positive & Supported $^{\mathrm{c}}$ \\
\hline $\mathrm{H} 3$ & Perceived usefulness and attitude & .801 & $19.093(1876)$ & $<.001$ & Positive & Supported ${ }^{\mathrm{b}}$ \\
\hline $\mathrm{H} 4$ & Perceived fear and perceived usefulness & .358 & $4.936(1876)$ & .04 & Positive & Supported $^{\mathrm{d}}$ \\
\hline H5 & Perceived usefulness and subjective norm & .227 & $4.660(1876)$ & .03 & Positive & Supported $^{\mathrm{d}}$ \\
\hline H6 & Perceived fear and subjective norm & .480 & $5.892(1876)$ & .04 & Positive & Supported $^{\mathrm{d}}$ \\
\hline H7 & Attitude and intention to use a mobile platform & .707 & $15.337(1876)$ & $<.001$ & Positive & Supported $^{\mathrm{b}}$ \\
\hline H8 & Subjective norm and intention to use a mobile platform & .553 & $19.485(1876)$ & $<.001$ & Positive & Supported $^{\mathrm{b}}$ \\
\hline H9 & $\begin{array}{l}\text { Perceived behavioral control and intention to use a } \\
\text { mobile platform }\end{array}$ & .148 & $18.089(1876)$ & $<.001$ & Positive & Supported $^{\mathrm{b}}$ \\
\hline
\end{tabular}

${ }^{\mathrm{a}}$ The $t$ test conducted was 2-tailed.

${ }^{\mathrm{b}}$ The hypothesis is supported based on a significant $P$ value of $\leq .001$.

${ }^{\mathrm{c}}$ The hypothesis is supported based on a significant $P$ value of $\leq .01$.

${ }^{\mathrm{d}}$ The hypothesis is supported based on a significant $P$ value of $<.05$.

\section{Hypotheses Testing With Machine Learning Algorithms}

This study was conducted with the assistance machine learning classification algorithms, which were applied through various methodologies, such as neural networks, if-then-else statements, decision trees, and Bayesian networks. Machine learning algorithms were used to predict the relationships in the proposed theoretical model $[69,76,77]$. With the help of Weka (version 3.8.3), the predictive model was tested on the basis of different classifiers, such as the OneR, J48, Logistic, LWL (Locally Weighted Learning), AdaBoostM1, and BayesNet classifiers $[78,79]$. In terms of predicting the PU of mobile learning systems, the $\mathrm{J} 48$ classifier performed better than the other classifiers, as seen from the results in Table 9. In the 10-fold cross-validation, the J48 classifier had an accuracy of $83.76 \%$ when predicting PU. Accordingly, these results supported hypotheses $\mathrm{H} 2$ and $\mathrm{H} 4$. The $\mathrm{J} 48$ classifier performed better than the other classifiers because of its high true positive rate (.837), precision (.803) and recall value (.838).

In terms of predicting attitude, the J48 classifier performed better than the other classifiers, as seen from the results in Table 10 . The $\mathrm{J} 48$ classifier was able to use PU to predict attitude with an accuracy of $80.13 \%$. Accordingly, these results supported hypothesis $\mathrm{H} 3$.

The results in Table 11 suggest that the $\mathrm{J} 48$ classifier performed better than the other classifiers when it came to predicting the SN based on the PEOU, PU, and PF. By using these constructs, the J48 classifier could predict the SN with an accuracy of $89.37 \%$. Accordingly, these results supported hypotheses H1, H5, and H6.

According to the results in Table 12, the J48 classifier performed better than the other classifiers when it came to predicting the intention to use a mobile learning platform based on attitude, the SN, and PBC. When predicting the intention to use a mobile learning platform, the $\mathrm{J} 48$ classifier had an accuracy of $86.66 \%$. These results supported hypotheses H7, H8, and $\mathrm{H} 9$. 
Table 9. Predicting perceived usefulness based on the perceived ease of use and perceived fear.

\begin{tabular}{lllllll}
\hline Classifier & $\mathrm{CCI}^{\mathrm{a}}, \%$ & $\mathrm{TP}^{\mathrm{b}}$ rate & $\mathrm{FP}^{\mathrm{c}}$ rate & Precision & Recall & \multicolumn{2}{c}{ F measure } \\
\hline BayesNet & 80.11 & .801 & .295 & .721 & .801 & .790 \\
Logistic & 81.02 & .810 & .308 & .735 & .705 & .798 \\
LWL & 80.54 & .805 & .339 & .732 & .821 & .801 \\
AdaBoostM1 & 82.10 & .821 & .337 & .712 & .820 & .819 \\
OneR & 81.66 & .816 & .834 & .803 & .838 & .816 \\
$\mathrm{~J} 48$ & 83.76 & .837 & & & .828 \\
\hline
\end{tabular}

${ }^{\mathrm{a} C C I}$ : correctly classified instances.

${ }^{\mathrm{b}} \mathrm{TP}$ : true positive.

${ }^{\mathrm{c}}$ FP: false positive.

${ }^{\mathrm{d}}$ LWL: Locally Weighted Learning.

Table 10. Predicting attitude based on perceived usefulness.

\begin{tabular}{lllllll}
\hline Classifier & $\mathrm{CCI}^{\mathrm{a}}, \%$ & $\mathrm{TP}^{\mathrm{b}}$ rate & $\mathrm{FP}^{\mathrm{c}}$ rate & Precision & Recall & \multicolumn{2}{c}{$\mathrm{F} \mathrm{measure}$} \\
\hline BayesNet & 78.02 & .780 & .229 & .735 & .781 & .726 \\
Logistic & 77.22 & .772 & .205 & .737 & .723 & .728 \\
LWL $^{\mathrm{d}}$ & 76.79 & .767 & .269 & .700 & .768 & .687 \\
AdaBoostM1 & 78.11 & .781 & .301 & .754 & .782 & .776 \\
OneR & 79.61 & .796 & .801 & .780 & .801 & .798 \\
$\mathrm{~J} 48$ & 80.13 & & & & .800 \\
\hline
\end{tabular}

${ }^{\mathrm{a} C C I}$ : correctly classified instances.

${ }^{\mathrm{b}} \mathrm{TP}$ : true positive.

${ }^{\mathrm{c}} \mathrm{FP}$ : false positive.

${ }^{\mathrm{d}}$ LWL: Locally Weighted Learning.

Table 11. Predicting the subjective norm based on the perceived ease of use, perceived usefulness, and perceived fear.

\begin{tabular}{lllllll}
\hline Classifier & $\mathrm{CCI}^{\mathrm{a}}, \%$ & $\mathrm{TP}^{\mathrm{b}}$ rate & $\mathrm{FP}^{\mathrm{c}}$ rate & \multicolumn{2}{c}{ Precision } & \multicolumn{2}{c}{ Recall measure } \\
\hline BayesNet & 80.76 & .807 & .311 & .760 & .810 & .758 \\
Logistic & 80.63 & .806 & .369 & .762 & .810 & .759 \\
LWL & 80.06 & .800 & .299 & .756 & .801 & .748 \\
AdaBoostM1 & 81.37 & .813 & .878 & .763 & .814 & .760 \\
OneR & 82.79 & .827 & .598 & .772 & .833 & .772 \\
$\mathrm{~J} 48$ & 89.37 & .893 & & & .894 & .782 \\
\hline
\end{tabular}

${ }^{\mathrm{a} C C I}$ : correctly classified instances.

${ }^{\mathrm{T}} \mathrm{TP}$ : true positive.

${ }^{\mathrm{c}} \mathrm{FP}$ : false positive.

${ }^{\mathrm{d}}$ LWL: Locally Weighted Learning. 
Table 12. Predicting the intention to use a mobile learning platform based on attitude, the subjective norm, and perceived behavioral control.

\begin{tabular}{|c|c|c|c|c|c|c|}
\hline Classifier & $\mathrm{CCI}^{\mathrm{a}}, \%$ & $\mathrm{TP}^{\mathrm{b}}$ rate & $\mathrm{FP}^{\mathrm{c}}$ rate & Precision & Recall & F measure \\
\hline BayesNet & 81.10 & .811 & .303 & .753 & .812 & .750 \\
\hline Logistic & 81.23 & .812 & .371 & .758 & .813 & .752 \\
\hline $\mathrm{LWL}^{\mathrm{d}}$ & 80.73 & .807 & .389 & .751 & .812 & .750 \\
\hline AdaBoostM1 & 81.44 & .814 & .369 & .762 & .815 & .761 \\
\hline OneR & 83.76 & .837 & .396 & .770 & .841 & .768 \\
\hline $\mathrm{J} 48$ & 86.66 & .866 & .595 & .802 & .872 & .798 \\
\hline
\end{tabular}

${ }^{\mathrm{a}} \mathrm{CCI}$ : correctly classified instances.

$\mathrm{b}_{\mathrm{TP}}$ : true positive.

${ }^{\mathrm{c}} \mathrm{FP}$ : false positive.

${ }^{\mathrm{d}}$ LWL: Locally Weighted Learning.

\section{Discussion}

\section{Principal Findings}

To test our proposed model, we used a complementary approach that combined the use of PLS-SEM and machine learning classification algorithms. There are few studies that have aimed to use machine learning algorithms to predict the actual use of mobile learning systems. Accordingly, studies that use a complementary multianalytical approach can play a major role in information systems literature and research. It should also be noted that PLS-SEM can help with predicting a dependent variable and validating a conceptual model that aims to extend an existing theory [80]. Similarly, a dependent variable can also be predicted with the help of supervised machine learning algorithms (ie, machine learning algorithms with a predefined dependent variable) and independent variables [69]. Another aspect of our study was the use of various classification algorithms in conjunction with the application of various methodologies, including if-then-else rules, neural networks, association rules, Bayesian networks, and decision trees. The J48 decision tree typically performed better than the other classifiers, as determined by our findings. Furthermore, we used a nonparametric decision tree to classify both categorical and continuous (ie, numerical) variables to obtain homogeneous subsamples from our main sample, on the basis of the main independent variable [69]. In other words, we used the nonparametric PLS-SEM technique to determine the significance of coefficients by using sample replacements, which were drawn from numerous subsamples on a random basis. This analysis provided empirical evidence for the impact of using mobile learning platforms during the COVID-19 pandemic. Our hypotheses (ie, H1, H5 and H6) significantly and positively supported the relationships between the SN and PEOU $(P=.001)$, the SN and PU $(P=.03)$, and the SN and PF $(P=.04)$. Numerous research studies have assessed the relationship between the SN and PEOU, the SN and PU, and the SN and PF [23,41,43-45]. Moreover, our analysis provided empirical evidence for the effect of the PEOU on PU, as proposed in hypothesis H2. Our results showed that this effect was positive and significant $(P=.002)$. Therefore, hypothesis $\mathrm{H} 2$ was in line with the findings of various studies [47-50].
Our analysis also provided empirical evidence for the effect of PU on attitude, as proposed in hypothesis H3. Our results showed that the effect was positive and significant $(P<.001)$. Therefore, hypothesis $\mathrm{H} 3$ was in line with the findings of various studies $[41,43-45,49]$. PF also had a significant effect on PU $(P=.04)$, which supported hypothesis H4 [23]. The seventh, eighth, and ninth hypotheses (ie, H7, H8, and H9) were developed to determine whether attitude, the SN, and PBC affected people's intention to use a mobile learning platform. Our results showed that the effects attitude $(P<.001)$, the SN $(P<.001)$, and PBC $(P<.001)$ on people's intention to use a mobile learning platform were positive and significant. Therefore, H7, H8, and $\mathrm{H} 9$ were in line with the findings of various studies [49,50,56-58,63]. Our analysis strongly supported the proposed research model. The findings of other researchers [23,41,43-45,47-50,56-58,63] and our results have similarities.

Research studies have assessed the influence of the COVID-19 pandemic on modern technology, specifically the effects of the pandemic on technology that is used for learning and teaching. Technology is an effective tool that provides a new and viable platform for enabling the continuation of teaching and learning during lockdown [81]. Therefore, this study aimed to analyze the influence that COVID-19 has on teaching practices, by using machine learning algorithms. Our research model emphasized the effects of PF, which had an extraordinary influence on measuring the effects of COVID-19 on student and teacher groups. Furthermore, our analysis was able to assess the influence of the pandemic on mobile learning technologies that are used for teaching. Hence, our study helps with removing the identified gaps in the field and establishing a basis for future research on mobile learning and teaching practices.

\section{Theoretical and Practical Implications}

Our analysis contributes to existing literature by exploring the primary impediments that hinder the effective use of mobile learning systems during the COVID-19 pandemic. This study provides several important practical findings with regard to the use and adoption of mobile learning systems in limited-income states, such as the UAE. For instance, previous research has only highlighted infrastructure as the main impediment to the use of e-learning systems [16-19], but in reality, various other 
factors also pose a challenge to mobile learning technology adoption. These impediments include specialized issues that relate to mobile learning frameworks. Such issues include changes in management, problems related to course designs, computer knowledge issues, and monetary issues. Based on the results of our study, we can provide helpful proposals to policy makers, designers, developers, and researchers. These proposals will enable them to achieve greater familiarity with the important elements of successful mobile learning system adoption.

The first proposal is that important technical resources for the continuous technical maintenance of mobile learning platforms must be provided by university administrations and technical support staff, to encourage the extensive adoption of mobile learning materials and prevent specialized issues or postponements. The second proposal is that the successful implementation of mobile learning technologies by students and instructors should only occur if the essential hardware, software, and internet connectivity are provided by university administrations. Additionally, these university administrations should provide consistent upgrades for technological resources. The third proposal is that designers and developers need to develop mobile learning systems that are user-friendly, easy to use, and not complicated. When students and instructors find that mobile learning systems are easy to use and user-friendly, they will be encouraged to use mobile learning systems. The fourth proposal is that policy makers at UAE universities should resort to new policies and guidelines that encourage the use of mobile learning systems among students and teachers. In addition, policy makers should adjust educational policies to guarantee an adaptable transition from traditional learning to mobile learning. Support from top management is imperative in technology progression. Moreover, technology progression requires training programs to ensure that mobile learning system-related institutional principles are being promoted and strictly followed by teachers. The fifth proposal is that the outcomes of our study can help university policy makers concentrate on enhancing teachers' educational technology knowledge by arranging training programs on methods for using mobile learning systems. Such training programs are essential, since teachers' educational technology-related knowledge and skills are likely to convince students to use mobile learning systems, which will lead to better teacher performance and improved student efficiency. The sixth proposal is that universities need to concentrate on promoting mobile learning systems through training courses that highlight the benefits of using mobile learning systems. Universities must also focus on developing students' competency in using information technology. The main reason for this is that students' expertise in computer studies and positive views on mobile learning systems have a favorable impact on the success of mobile learning systems. Based on the outcomes of our study, we can provide a better understanding of mobile learning systems and offer recommendations for effectively implementing mobile learning systems during the course of the COVID-19 pandemic.

\section{Limitations and Future Research}

It is necessary to report on various key limitations of this study. First, caution needs to be taken when generalizing our results to other institutes in the UAE or other parts of the world. This is attributed to the fact that we only collected data from 7 education institutions. Additionally, participants were selected based on a convenience sampling technique. If these limitations are considered, future research can contribute to the generalization of our results. Second, this study only evaluated students' actual use of mobile learning systems. Future research should also focus on teachers' actual use of mobile learning systems, so that more information on influencing factors and system implementation can be determined.

\section{Recommendations}

With regard to web-based teaching, a mobile learning platform is considered to be a safe environment. During the COVID-19 pandemic, web-based teaching systems have been recommended. During the lockdown, web-based teaching systems have been considered a temporary solution. The availability of machine learning has promptly provided students and teachers with self-sensing security and communication tools. For example, in the UAE, Sharjah City was affected by the spread of the SARS-CoV-2 virus, and as a result, a web-based mobile learning tool has proved to be quite useful. This mobile learning platform has various advantages over other communication platforms. First, this platform can be used on laptops and smartphones; the students of the University of Sharjah have joined and participated in classes by using this platform on their smartphones. Second, the links to each class period can be used at various times, thereby allowing students to communicate with teachers at any point in time during the day. Third, the students have been much more confident, and their feelings of fear have been minimized.

\section{Conclusion}

This study's results are similar to those presented in earlier research studies on the importance of variables in the TAM and TPB model $[41,42,44,45]$. We observed that during the COVID-19 pandemic, students were much more accepting of technology if mobile learning technology was the only available tool for learning. Our PU-related and PEOU-related results are also similar to those of other studies that have assessed the influence of PU and the PEOU on students' acceptance of mobile learning technology. Therefore, PU and the PEOU should be considered indicators of students' willingness to use mobile learning platforms during the COVID-19 pandemic. Furthermore, PU was highly affected by the PEOU, which indicates that if a technology is easy to use, then it is also considered useful. Additionally, according to our results, there was a significant association between students' acceptance of mobile learning technology and the subjective norm $(P<.001)$.

Studies have indicated that students' behavior within the classroom, their behavior in daily life, and their reactions to the use of mobile learning technology highly affect their acceptance of mobile learning technology. Previous research studies [45,52-54] have also stated that the SN and students' acceptance of mobile learning technology are associated. In the UAE, students are considerably influenced by their classmates' behaviors. This influence has increased the sense of security and comfort of students who have attended classes during the pandemic. Furthermore, students are motivated to use mobile learning technology to spend time with people who attend the 
same class. Additionally, there were several variables that significantly influenced the SN, other than the PEOU and PU. According to our results, instructors' and students' attitudes also helped to promote the use of mobile learning platforms as a learning tool during the pandemic period. If students and teachers have positive attitudes toward the use of mobile learning tools, they will perceive such tools to be useful, enjoyable, and effort free.

Our findings are consistent with those of previous studies [82]. For example, it has been stated that peers, students, and instructors provide useful feedback that affects students' attitudes and perceptions toward technology effectiveness. Due to the COVID-19 pandemic, fear has been on the rise. This should be considered an essential topic for future research, as the human population continues to be severely affected by the
COVID-19 pandemic. The SARS-CoV-2 virus has a high probability of transmission, which is why there is a need for complete lockdown and stay-at-home strategies throughout the world [83]. In this study, we developed a model that is useful for conducting future studies, as our model can help with assessing the influence of COVID-19 during the pandemic period. Based on our study results and the rise of fear during the pandemic period, we believe that mobile learning technologies are important and useful tools that help to reduce students' and instructors' fear. In our study, PF highly affected PU and the PEOU. Furthermore, according to the responses we received, fear was quite evident during the pandemic period. However, mobile learning platforms maintained a high degree of PU and PEOU, which reduced fear and encouraged students to participate in their scheduled classes.

\section{Conflicts of Interest}

None declared.

\section{References}

1. Al-Maroof RS, Alfaisal AM, Salloum SA. Google glass adoption in the educational environment: A case study in the Gulf area. Educ Inf Technol (Dordr) 2020 Nov 03:1-24 [FREE Full text] [doi: 10.1007/s10639-020-10367-1]

2. Al-Maroof RS, Alhumaid K, Salloum S. The Continuous Intention to Use E-Learning, from Two Different Perspectives. Educ Sci (Basel) 2020 Dec 25;11(1):6 [FREE Full text] [doi: 10.3390/educsci11010006]

3. Al Kurdi B, Alshurideh M, Salloum SA. Investigating a theoretical framework for e-learning technology acceptance. International Journal of Electical and Computer Engineering 2020 Dec 01;10(6):6484-6496 [FREE Full text] [doi: 10.11591/ijece.v10i6.pp6484-6496]

4. Ahorsu DK, Lin CY, Imani V, Saffari M, Griffiths MD, Pakpour AH. The Fear of COVID-19 Scale: Development and Initial Validation. Int J Ment Health Addict 2020 Mar 27:1-9 [FREE Full text] [doi: 10.1007/s 11469-020-00270-8] [Medline: 32226353]

5. Lin CY. Social reaction toward the 2019 novel coronavirus (COVID-19). Social Health and Behavior 2020;3(1):1-2 [FREE Full text] [doi: 10.4103/SHB.SHB 11 20]

6. Pappas G, Kiriaze IJ, Giannakis P, Falagas ME. Psychosocial consequences of infectious diseases. Clin Microbiol Infect 2009 Aug;15(8):743-747 [FREE Full text] [doi: 10.1111/j.1469-0691.2009.02947.x] [Medline: 19754730]

7. Morchid N. The Current State of Technology Acceptance: A Comparative Study. Journal of Business and Management 2020 Feb;22(2):1-16 [FREE Full text] [doi: 10.9790/487X-2202030116]

8. Alt D, Boniel-Nissim M. Links between Adolescents' Deep and Surface Learning Approaches, Problematic Internet Use, and Fear of Missing Out (FoMO). Internet Interv 2018 Sep;13:30-39 [FREE Full text] [doi: 10.1016/j.invent.2018.05.002] [Medline: 30206516 ]

9. Ellahi A. Fear of using technology: Investigating impact of using social networking sites in business education. 2017 Presented at: 2017 IEEE 15th Student Conference on Research and Development (SCOReD); December 13-14, 2017; Putrajaya, Malaysia p. 234-237. [doi: 10.1109/SCORED.2017.8305387]

10. Machů E, Morysová D. Analysis of the Emotion of Fear in Gifted Children and its Use in Teaching Practice. Procedia Soc Behav Sci 2016 Feb 05;217(5):222-228 [FREE Full text] [doi: 10.1016/j.sbspro.2016.02.071]

11. Li L, Chen Y, Li Z, Li D, Li F, Huang H. Online Virtual Experiment Teaching Platform for Database Technology and Application. 2018 Presented at: 2018 13th International Conference on Computer Science \& Education (ICCSE); August 8-11, 2018; Colombo, Sri Lanka p. 1-5. [doi: 10.1109/ICCSE.2018.8468849]

12. Liang Y, Zheng T, Wang M. English audio-visual teaching mode and its teaching environment construction — Henan institute of science and technology as the example. 2011 Presented at: 2011 International Conference on Multimedia Technology; July 26-28, 2011; Hangzhou, China p. 3050-3053. [doi: 10.1109/ICMT.2011.6001924]

13. Chen E, Li Z. On the application of multimedia technology in foreign language teaching and learning in China's colleges: Challenges, problems and implications. 2011 Presented at: 2011 International Conference on Multimedia Technology; July 26-28, 2011; Hangzhou, China p. 595-597. [doi: 10.1109/ICMT.2011.6001903]

14. Alshurideh M, Al Kurdi B, Salloum SA. Examining the Main Mobile Learning System Drivers' Effects: A Mix Empirical Examination of Both the Expectation-Confirmation Model (ECM) and the Technology Acceptance Model (TAM). In: Proceedings of the International Conference on Advanced Intelligent Systems and Informatics 2019. 2019 Oct 02 Presented at: 5th International Conference on Advanced Intelligent Systems and Informatics 2019 (AISI2019); October 26-28, 2019; Cairo, Egypt p. 406-417. [doi: 10.1007/978-3-030-31129-2 37] 
15. Al Kurdi B, Alshurideh M, Salloum SA, Obeidat ZM, Al-dweeri RM. An Empirical Investigation into Examination of Factors Influencing University Students' Behavior towards Elearning Acceptance Using SEM Approach. International Journal of Interactive Mobile Technologies 2020 Feb 10;14(2):19-41. [doi: 10.3991/ijim.v14i02.11115]

16. Almaiah MA, Al Mulhem A. A conceptual framework for determining the success factors of E-learning system implementation using Delphi technique. Journal of Theoretical and Applied Information Technology 2018 Sep;96(17):1-15 [FREE Full text]

17. Almaiah MA, Alyoussef IY. Analysis of the Effect of Course Design, Course Content Support, Course Assessment and Instructor Characteristics on the Actual Use of E-Learning System. IEEE Access 2019 Nov 27;7:171907-171922 [FREE Full text] [doi: 10.1109/ACCESS.2019.2956349]

18. Eltahir ME. E-Learning in Developing Countries: Is it a Panacea? A Case Study of Sudan. IEEE Access 2019;7:97784-97792 [FREE Full text] [doi: 10.1109/access.2019.2930411]

19. Chen HR, Tseng HF. Factors that influence acceptance of web-based e-learning systems for the in-service education of junior high school teachers in Taiwan. Eval Program Plann 2012 Aug;35(3):398-406. [doi: 10.1016/j.evalprogplan.2011.11.007] [Medline: 22321703]

20. McIlroy S, Ali N, Hassan AE. Fresh apps: an empirical study of frequently-updated mobile apps in the Google play store. Empir Softw Eng 2015 Jul 7;21(3):1346-1370 [FREE Full text] [doi: 10.1007/s10664-015-9388-2]

21. Liu CZ, Au YA, Choi HS. Effects of Freemium Strategy in the Mobile App Market: An Empirical Study of Google Play. J Manag Inf Syst 2015 Mar 09;31(3):326-354. [doi: 10.1080/07421222.2014.995564]

22. Al-Emran M. Mobile learning during the era of COVID-19. Revista Virtual Universidad Católica del Norte 2020 Dec;1(61):1-2. [doi: 10.35575/rvucn.n61a1]

23. Al-Maroof RS, Salloum SA, Hassanien AE, Shaalan K. Fear from COVID-19 and technology adoption: the impact of Google Meet during Coronavirus pandemic. Interactive Learning Environments 2020 Oct 14:1-16 [FREE Full text] [doi: $\underline{10.1080 / 10494820.2020 .1830121]}$

24. Liu Q, Geertshuis S, Grainger R. Understanding academics' adoption of learning technologies: A systematic review. Comput Educ 2020 Jul;151:103857. [doi: 10.1016/j.compedu.2020.103857]

25. Tsai T, Lin WY, Chang YS, Chang PC, Lee MY. Technology anxiety and resistance to change behavioral study of a wearable cardiac warming system using an extended TAM for older adults. PLoS One 2020 Jan 13;15(1):e0227270. [doi: 10.1371/journal.pone.0227270] [Medline: 31929560]

26. Mahmud MS, Talukder MU, Rahman SM. Does 'Fear of COVID-19' trigger future career anxiety? An empirical investigation considering depression from COVID-19 as a mediator. Int J Soc Psychiatry. Epub ahead of print 2020 Jul 02 [FREE Full text] [doi: 10.1177/0020764020935488] [Medline: $\underline{32615833]}$

27. Patil P, Tamilmani K, Rana NP, Raghavan V. Understanding consumer adoption of mobile payment in India: Extending Meta-UTAUT model with personal innovativeness, anxiety, trust, and grievance redressal. Int J Inf Manag 2020 Oct;54:102144. [doi: 10.1016/j.ijinfomgt.2020.102144]

28. Thatcher JB, Perrewé PL. An Empirical Examination of Individual Traits as Antecedents to Computer Anxiety and Computer Self-Efficacy. MIS Quarterly 2002 Dec;26(4):281-296. [doi: 10.2307/4132314]

29. Callum KM, Jeffrey L, Kinshuk. Comparing the role of ICT literacy and anxiety in the adoption of mobile learning. Comput Human Behav 2014 Oct;39:8-19. [doi: 10.1016/j.chb.2014.05.024]

30. Nchunge DM, Sakwa M, Mwangi W. User's Perception on Ict Adoption For Education Support in Schools: A Survey of Secondary School Teacher's in Thika District Kenya. Int J Humanit Soc Sci 2012 May;2(10):17-29.

31. Meng F, Guo X, Zhang X, Peng Z, Lai KH. Examining the Role of Technology Anxiety and Health Anxiety on Elderly Users' Continuance Intention for Mobile Health Services Use. 2020 Presented at: Proceedings of the 53rd Hawaii International Conference on System Sciences; January 7-10, 2020; Maui, Hawaii p. 3297-3306 URL: https://scholarspace. manoa.hawaii.edu/bitstream/10125/64145/0325.pdf [doi: 10.24251/hicss.2020.403]

32. Kamal SA, Shafiq M, Kakria P. Investigating acceptance of telemedicine services through an extended technology acceptance model (TAM). Technol Soc 2020 Feb;60:101212. [doi: 10.1016/j.techsoc.2019.101212]

33. Bailey AA, Pentina I, Mishra AS, Mimoun MSB. Exploring factors influencing US millennial consumers' use of tap-and-go payment technology. The International Review of Retail, Distribution and Consumer Research 2019 Oct 22;20(2):143-163. [doi: 10.1080/09593969.2019.1667854]

34. Makttoofa N, Khalidb H, Abdullahc I. The Effect of Individual Factors on the Adoption of Mobile Banking Within Banks in Iraq. International Journal of Innovation, Creativity and Change 2020;11(9):73-90 [FREE Full text]

35. Bhattacherjee A, Hikmet N. Physicians' resistance toward healthcare information technology: a theoretical model and empirical test. Eur J Inf Syst 2007;16(7):725-737. [doi: 10.1057/palgrave.ejis.3000717]

36. Johnston AC, Warkentin M. Fear Appeals and Information Security Behaviors: An Empirical Study. MIS Quarterly 2010;34(3):549-566. [doi: 10.2307/25750691]

37. Brown SA, Venkatesh V. Model of Adoption of Technology in Households: A Baseline Model Test and Extension Incorporating Household Life Cycle. MIS Quarterly 2005;29(3):399-426. [doi: 10.2307/25148690]

38. Gresham J. Manufacturing Trends in Automated Inspection Equipment: Linking Technology with Business Change Management Using the Technology Acceptance Model. ProQuest Dissertations Publishing. 2020. URL: https://search. 
proquest.com/openview/82f13c4295726875d44bb2d1374cfeba/1?pq-origsite $=$ gscholar \&cbl=18750\&diss=y [accessed 2021-01-14]

39. Appavoo P. Acceptance of Technology in the Classroom: A Qualitative Analysis of Mathematics Teachers' Perceptions. Frontiers in Intelligent Computing: Theory and Applications 2019 Oct 02;1014:355-364.

40. Distler V, Lallemand C, Koenig V. How Acceptable Is This? How User Experience Factors Can Broaden our Understanding of The Acceptance of Privacy Trade-offs. Comput Human Behav 2020 May;106:106227 [FREE Full text] [doi: 10.1016/j.chb.2019.106227]

41. Davis FD. Perceived Usefulness, Perceived Ease of Use, and User Acceptance of Information Technology. MIS Quarterly 1989 Sep;13(3):319-340. [doi: $\underline{10.2307 / 249008]}$

42. Ajzen I. From Intentions to Actions: A Theory of Planned Behavior. In: Action Control. Berlin, Heidelberg: Springer; 1985.

43. Al-Maroof RAS, Al-Emran M. Students Acceptance of Google Classroom: An Exploratory Study using PLS-SEM Approach. International Journal of Emerging Technologies in Learning 2018 May 29;13(6):112-123. [doi: 10.3991/ijet.v13i06.8275]

44. Teo T. Examining the intention to use technology among pre-service teachers: an integration of the Technology Acceptance Model and Theory of Planned Behavior. Interactive Learning Environments 2012 Feb;20(1):3-18. [doi: 10.1080/10494821003714632]

45. Venkatesh V, Bala H. Technology Acceptance Model 3 and a Research Agenda on Interventions. Decision Sciences 2008 May 09;39(2):273-315. [doi: 10.1111/j.1540-5915.2008.00192.x]

46. Karjaluoto H, Mattila M, Pento T. Factors underlying attitude formation towards online banking in Finland. International Journal of Bank Marketing 2002 Nov 01;20(6):261-272. [doi: 10.1108/02652320210446724]

47. Khanh NTV, Gim G. Factors Influencing Mobile-Learning Adoption Intention: An Empirical Investigation In High Education. Journal of Social Sciences 2014 Feb 01;10(2):51-62. [doi: 10.3844/jssp.2014.51.62]

48. Prieto JCS, Migueláñez SO, García-Peñalvo FJ. Mobile learning adoption from informal into formal: an extended TAM model to measure mobile acceptance among teachers. 2014 Oct Presented at: TEEM '14: 2nd International Conference on Technological Ecosystems for Enhancing Multiculturality; October, 2014; Salamanca, Spain p. 592-602. [doi: $10.1145 / 2669711.2669961]$

49. Al-Emran M, Arpaci I, Salloum SA. An empirical examination of continuous intention to use m-learning: An integrated model. Educ Inf Technol (Dordr) 2020 Jan 04;25:2899-2918 [FREE Full text] [doi: 10.1007/s10639-019-10094-2]

50. Cheon J, Lee S, Crooks SM, Song J. An investigation of mobile learning readiness in higher education based on the theory of planned behavior. Comput Educ 2012 Nov;59(3):1054-1064. [doi: 10.1016/j.compedu.2012.04.015]

51. Fishbein M, Ajzen I. Belief, Attitude, Intention and Behavior: An Introduction to Theory and Research. Contemp Sociol 1977 Mar;6(2):244-245. [doi: 10.2307/2065853]

52. Song Y, Kong SC. Investigating Students' Acceptance of a Statistics Learning Platform Using Technology Acceptance Model. Journal of Educational Computing Research 2017 Jan 18;55(6):865-897. [doi: 10.1177/0735633116688320]

53. Wong KT, Teo T, Russo S. Influence of gender and computer teaching efficacy on computer acceptance among Malaysian student teachers: An extended technology acceptance model. Australian Journal of Educational Technology 2012 Aug 28;28(7):1190-1207 [FREE Full text] [doi: 10.14742/ajet.796]

54. Venkatesh V, Davis FD. A Theoretical Extension of the Technology Acceptance Model: Four Longitudinal Field Studies. Management Science 2000 Feb 01;46(2):186-204. [doi: 10.1287/mnsc.46.2.186.11926]

55. Huang F, Teo T, Zhou M. Chinese students' intentions to use the Internet-based technology for learning. Education Tech Research Dev 2019 Jul 17;68(1):575-591 [FREE Full text] [doi: 10.1007/s11423-019-09695-y]

56. Liu Y, Chen NS. An adoption model for mobile learning. 2008 Presented at: IADIS International Conference e-Commerce 2008; July 2008; Amsterdam, The Netherlands p. 235-240.

57. Mtebe JS, Raisamo R. Investigating students' behavioural intention to adopt and use mobile learning in higher education in East Africa. International Journal of Education and Development using Information and Communication Technology 2014;10(3):4-20.

58. Park SY, Nam MW, Cha SB. University students' behavioral intention to use mobile learning: Evaluating the technology acceptance model. Br J Educ Technol 2011 Oct 04;43(4):592-605. [doi: 10.1111/j.1467-8535.2011.01229.x]

59. Nicomedes CJ, Avila RM. An Analysis on the Panic of Filipinos During COVID-19 Pandemic in the Philippines. ResearchGate. Preprint posted online on March 21, 2020 [FREE Full text] [doi: 10.13140/RG.2.2.17355.54565]

60. Gerhold L. COVID-19: Risk perception and Coping strategies. PsyArXive.Preprint posted online on September 23, 2020 Preprint posted online on September 23, 2020 [FREE Full text] [doi: 10.31234/osf.io/xmpk4]

61. Tarhini A, Hone K, Liu X. A cross-cultural examination of the impact of social, organisational and individual factors on educational technology acceptance between British and Lebanese university students. Br J Educ Technol 2014 May 13;46(4):739-755 [FREE Full text] [doi: 10.1111/bjet.12169]

62. Ajzen I. The theory of planned behavior. Organ Behav Hum Decis Process 1991 Dec;50(2):179-211. [doi: 10.1016/0749-5978(91)90020-t]

63. Kim B. An empirical investigation of mobile data service continuance: Incorporating the theory of planned behavior into the expectation-confirmation model. Expert Syst Appl 2010 Oct;37(10):7033-7039. [doi: 10.1016/j.eswa.2010.03.015] 
64. Tan GWH, Ooi KB, Leong LY, Lin B. Predicting the drivers of behavioral intention to use mobile learning: A hybrid SEM-Neural Networks approach. Comput Human Behav 2014 Jul;36:198-213. [doi: 10.1016/j.chb.2014.03.052]

65. Bao Y, Xiong T, Hu Z, Kibelloh M. Exploring Gender Differences on General and Specific Computer Self-Efficacy in Mobile Learning Adoption. Journal of Educational Computing Research 2013 Oct 18;49(1):111-132. [doi: 10.2190/EC.49.1.e]

66. Nunnally JC, Bernstein IH. Psychometric theory (3rd ed.). New York City: McGraw-Hill; 1994.

67. Ringle CM, Wende S, Becker JM. SmartPLS 3. In: A Primer on Partial Least Squares Structural Equation Modeling (PLS-SEM), Second Edition. New York: SAGE Publications; 2016.

68. Barclay DW, Higgins C, Thompson R. The Partial Least Squares (PLS) Approach to Causal Modeling: Personal Computer Use as an Illustration. Technology Studies 1995;2(2):285-309.

69. Arpaci I. A hybrid modeling approach for predicting the educational use of mobile cloud computing services in higher education. Comput Human Behav 2019 Jan;90:181-187. [doi: 10.1016/j.chb.2018.09.005]

70. Hair Jr JF, Hult GTM, Ringle C, Sarstedt M. A Primer on Partial Least Squares Structural Equation Modeling (PLS-SEM). New York: Sage Publications; 2016.

71. Fornell C, Larcker DF. Evaluating Structural Equation Models with Unobservable Variables and Measurement Error. J Mark Res 1981 Feb 01;18(1):39-50. [doi: 10.1177/002224378101800104]

72. Hair JF, Black WC, Babin BJ, Anderson RE. Multivariate Data Analysis (7th Edition). New York City: Pearson Education; 2009.

73. Henseler J, Ringle CM, Sarstedt M. A new criterion for assessing discriminant validity in variance-based structural equation modeling. J Acad Mark Sci 2014 Aug 22;43:115-135 [FREE Full text] [doi: 10.1007/s11747-014-0403-8]

74. Davis FD, Bagozzi RP, Warshaw PR. Extrinsic and Intrinsic Motivation to Use Computers in the Workplace1. J Appl Social Pyschol 1992 Jul;22(14):1111-1132. [doi: 10.1111/j.1559-1816.1992.tb00945.x]

75. Liu SH, Liao HL, Peng CJ. Applying the technology acceptance model and flow theory to online e-learning users' acceptance behavior. E-Learning 2005 Jan;4(2):H8.

76. Salloum SA, Alshurideh M, Elnagar A, Shaalan K. Mining in Educational Data: Review and Future Directions. In: Proceedings of the International Conference on Artificial Intelligence and Computer Vision (AICV2020). 2020 Mar 24 Presented at: Proceedings of the International Conference on Artificial Intelligence and Computer Vision (AICV2020); April 8-10, 2020; Cairo, Egypt. [doi: 10.1007/978-3-030-44289-7 9]

77. Salloum SA, Alshurideh M, Elnagar A, Shaalan K. Machine Learning and Deep Learning Techniques for Cybersecurity: A Review. In: Proceedings of the International Conference on Artificial Intelligence and Computer Vision (AICV2020). 2020 Presented at: The International Conference on Artificial Intelligence and Computer Vision (AICV2020); April 8-10, 2020; Cairo, Egypt. [doi: 10.1007/978-3-030-44289-7_5]

78. Frank E, Hall M, Holmes G, Kirkby R, Pfahringer B, Witten IH, et al. Weka-A Machine Learning Workbench for Data Mining. In: Data Mining and Knowledge Discovery Handbook. Boston, MA: Springer; 2009.

79. Alomari KM, Alhamad AQ, Mobaideen H, Salloum SA. Prediction of the Digital Game Rating Systems based on the ESRB. Opcion 2019 May;35(19):1368-1393 [FREE Full text]

80. Al-Emran M, Mezhuyev V, Kamaludin A. PLS-SEM in Information Systems Research: A Comprehensive Methodological Reference. In: Proceedings of the International Conference on Advanced Intelligent Systems and Informatics 2018. 2018 Presented at: The International Conference on Advanced Intelligent Systems and Informatics 2018; September 1-3, 2018; Cairo, Egypt p. 644-653. [doi: 10.1007/978-3-319-99010-1 59]

81. Kumar A, Gupta PK, Srivastava A. A review of modern technologies for tackling COVID-19 pandemic. Diabetes Metab Syndr 2020;14(4):569-573 [FREE Full text] [doi: 10.1016/j.dsx.2020.05.008] [Medline: 32413821]

82. El-Gayar OF, Moran M, Hawkes ML. Students' Acceptance of Tablet PCs and Implications for Educational Institutions. Educational Technology \& Society 2011 Apr;14(2):58-70.

83. Zhang SX, Wang Y, Rauch A, Wei F. Unprecedented disruption of lives and work: Health, distress and life satisfaction of working adults in China one month into the COVID-19 outbreak. Psychiatry Res 2020 Jun;288:112958 [FREE Full text] [doi: 10.1016/j.psychres.2020.112958] [Medline: $\underline{32283450]}$

\section{Abbreviations}

LWL: Locally Weighted Learning

PBC: perceived behavioral control

PEOU: perceived ease of use

PF: perceived fear

PLS-SEM: partial least squares-structural equation modeling

PU: perceived usefulness

SN: subjective norm

TAM: technology acceptance model

TPB: theory of planned behavior

UAE: United Arab Emirates 


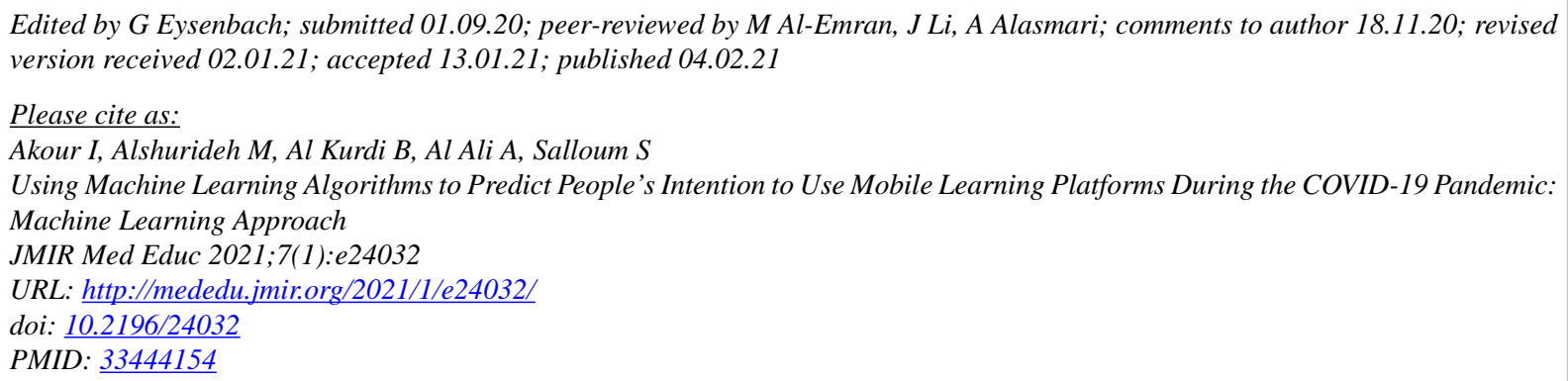

CIman Akour, Muhammad Alshurideh, Barween Al Kurdi, Amel Al Ali, Said Salloum. Originally published in JMIR Medical Education (http://mededu.jmir.org), 04.02.2021. This is an open-access article distributed under the terms of the Creative Commons Attribution License (https://creativecommons.org/licenses/by/4.0/), which permits unrestricted use, distribution, and reproduction in any medium, provided the original work, first published in JMIR Medical Education, is properly cited. The complete bibliographic information, a link to the original publication on http://mededu.jmir.org/, as well as this copyright and license information must be included. 